\title{
WAR Metaphor in the Chinese Economic Media Discourse
}

\author{
Chunyu $\mathrm{Hu}^{1}$ \& Yuting $\mathrm{Xu}^{1}$ \\ ${ }^{1}$ School of English for International Business, Guangdong University of Foreign Studies, China \\ Correspondence: Chunyu Hu, School of English for International Business, Guangdong University of Foreign \\ Studies, Guangzhou, 510420, China. Tel: 86-20-3631-7183. E-mail: gwhcy@gdufs.edu.cn
}

Received: Augest 16, 2016

Accepted: December 16, 2016 Online Published: February 20, 2017

doi:10.5539/hes.v7n1p94

URL: http://doi.org/10.5539/hes.v7n1p94

\begin{abstract}
The economic media discourse depends upon a complex web of metaphors, among which WAR metaphor is worthy of special attention. The data used in this study is comprised of 2566 articles (about 1.2 million words) under the Economy column of China Daily published in 2014. Critical Metaphor Analysis (CMA) is used as the analytical framework to investigate WAR metaphor in the economic media discourse. This study is governed by the three steps of CMA including metaphor identification, metaphor interpretation and metaphor explanation. The results show that among the selected 62 lemmas, 40 of them have metaphorical instantiations and more than half of all the metaphorical expressions are nouns. Both social resources and individual resources influence metaphor choice. WAR metaphor has the rhetorical function as persuasion, which constructs the cognitive model of competition in the mind of the readers and arouses their emotions; on the other hand, it hides the cooperative principle of economic activities.
\end{abstract}

Keywords: corpus, WAR metaphor, economic media discourse, Critical Metaphor Analysis

\section{Introduction}

Metaphor was traditionally viewed as fanciful decoration that adorns literary texts and high-flown rhetorical speeches which was based on the resemblance between two entities, a characteristic of language alone rather than thought or action. As a device of the poetic imagination and the rhetorical flourish, metaphor is not regarded as an inevitable part of everyday human thought and reasoning. Most people assume that one must have a special talent to be able to use metaphor, and only great poets or eloquent speakers can be its masters.

This entrenched view has been challenged by Lakoff and Johnson (1980) who outlined "Conceptual Metaphor Theory" (CMT). Since then, the importance of CMT has been well established by subsequent researchers in linguistics, philosophy and literary studies. As Lakoff and Johnson observe in their Philosophy in the Flesh (1999), substantial evidence makes it hard to deny that conceptual metaphors are real and can explain much about the way we think and speak. An important notion in CMT is the conceptual domain which can be viewed as any coherent organization of experience. Metaphor is defined as conceptualizing one domain of experience in terms of another, or more simply TARGET DOMAIN IS SOURCE DOMAIN (Lakoff, 1993). The source domain is typically more physical, more directly experienced, and better known than the target domain which is typically more abstract, less directly experienced, and less known. For instance, we have coherently organized knowledge about journey that we rely on in understanding life, leading to a common conceptual metaphor LIFE IS A JOURNEY.

Kövecses (2010, pp. 18-23) classifies the ordinary source domain into 13 categories including the human body, health and illness, animals, plants, buildings and construction, machines and tools, games and sports, money and economic transactions, cooking and food, heat and cold, light and darkness, forces as well as movement and direction. WAR metaphor is ignored, however.

WAR metaphor pervades in our life. The conceptual metaphor ARGUMENT IS WAR is highly entrenched in people's mind. Lakoff and Johnson (1980, pp. 63-64) claim that "even if you have never fought a fistfight in your life, much less a war, but have been arguing from the time you began to talk, you still conceive of arguments, and execute them, according to the ARGUMENT IS WAR metaphor because the metaphor is built into the conceptual system of the culture in which you live". Eubank (2000) asserts that TRADE IS WAR is a cognitive entrenched resource. One can hardly discuss trade at all if we cannot describe and comprehend trade as war, in that "we typically envision trade as an activity in which participants are belligerently opposed and aim to 
conquer or destroy" (Eubank, 2000, p. 25). From ARGUMENT IS WAR to TRADE IS WAR, it is evident that WAR metaphor plays an important role in human activity. Building on previous studies in this line of research, this paper aims to investigate the typical WAR metaphor in economic media discourse. The data of this research comes from the Economy column in the widely known Chinese daily newspaper, China Daily. Critical metaphor analysis is used as the analytical framework of this study.

\section{WAR Metaphor in Economic Discourses}

The previous corpus-based studies illustrate the frequent use of war metaphor in business and economic discourse. Koller (2004), for instance, investigates the business media discourse categorized by the topic of Marketing and Sales and Mergers and Acquisition. The data come from Business Week, The Economist, Fortune, Financial Times. 35 lemmas in the domain of WAR are selected and searched with the aid of Word Smith 3.0 tools. Based on computer assisted quantitative study and systematic functional linguistic qualitative study, WAR/FIGHTING metaphor is most frequent and most entrenched. The reason lies in its masculinized nature: "emphasis on that metaphor characterizes marketing discourse as a male arena and thus reifies the power of male readers. In addition, emphasis on the metaphor matches the cognitive schemata likely to be held by those readers" (Koller, 2004, p. 77). Her study demonstrates how the WAR or FIGHTING metaphor can become part of a wider metaphoric scenario of evolutionary struggle and Economic Darwinism, showing both specific [+HUMAN] and more general [+ANIMATE] features. Similarly, Wu (2010) finds that among those 10 identified structural metaphors, WAR metaphor accounts for the highest frequency.

Chen (2010) investigates the metaphor use in economic discourses before, during and after the implementation of the Reform and Opening-up policy, which is a significant turning point in Chinese history. The corpora consist of more than 370 Chinese economic texts in which 276 are from People's Daily (PD) and 100 from Xinmin Evening News and Wenhui Daily (XW). The metaphorical expressions are extracted by searching for source domain vocabulary. Her study reveals that the source domain of WAR is much more diversified after the reform. It involves such concept as belligerent parties, troops thrown in, weapons employed, commanders in the army, targets, strategies adopted, territory, manoeuvres of the army and results. By contrast, the economic war launched before the reform has no definite military targets, no appropriate strategies or good officers. This contrast is due to the liberation of human's mind and the confidence boosted by the success of the Reform and Opening-up policy.

Zhang (2011) compares the metaphor use of Olympic economic discourse in Chinese and American media. The 170 electronic texts are retrieved from the websites of the following periodicals and newspapers: Business Week (BW), China Economics Weekly (CEW), The New York Times (NYT) and People's Daily (PD). The selected articles which contain the phrase ao yun jing ji (奥运经济) in Chinese and its English equivalent "Olympic Economy" as well as the word "Beijing" in American media that are published between September 1, 2001 and December 31, 2008. The metaphorical expressions are found by manual survey. These metaphorical expressions are classified into different groups according to the source domain they adopt by identifying their basic meaning. There are some shared metaphorical expressions in both media like both media construct Olympic economy by virtue of basic human experience. The difference lies in that Chinese media shows more frequent occurrence of WAR metaphor while the American media is inclined to use ORGANISM metaphor. The results reflect different social-cultural perspective on Olympic economy between Chinese and American media.

In searching for inflation metaphor in COCA, Hu and Chen (2015) notices that the conceptual metaphor INFLATION IS AN ENEMY is in line with the metaphoric theme of fighting and warfare. As an enemy, inflation seems to have the power to cripple one's presidency, to rip a country, and to besiege the public, to hurt payments, and to injure certain classes.

The importance of war metaphor in modern economy cannot be overestimated. Although WAR metaphor is frequently used in both English and Chinese economic media discourse, the specialized investigation of this type of metaphor and the motivation for such metaphor choice is rare and inadequate. This paper aims to fill in the gap.

\section{Theoretical Framework: Critical Metaphor Analysis}

Critical Metaphor Analysis (CMA), put forward by Charteris-Black (2004), is an integration of pragmatics, rhetoric, cognitive linguistics, critical discourse analysis and corpus linguistics, which aims to reveal the unconscious intentions of the language users. Metaphor plays an effective function in extending and diversifying the linguistic system to accommodate new change in the conceptual system in the semantic aspect. Besides, metaphor reflects the metaphor choice that realizes the rhetorical intentions within a particular context. This is the pragmatic role played by metaphor. Charteris-Black argues that the pragmatic approach to metaphor should 
also be taken into consideration because metaphors are often used in specific communication context. Cognitive semantics provides a better explanation of how metaphors are understood without answering why they are chosen in a particular discourse for the purpose of persuasion. The pragmatic perspective of metaphor complements the cognitive semantic approach in that it interprets the metaphor choice with reference to the purpose of use within specific context. Generally speaking, the pragmatic perspective of metaphor takes metaphor back to the rhetorical origin. The rhetoric function of metaphor in public speech is to persuade the audience to accept certain viewpoints. Therefore, it is speaker intention that governs the choice of metaphor and plays a decisive role in understanding what metaphor is. Critical analysis of the context of metaphors in large corpora may reveal the underlying intentions of the text producer and therefore serves to identify the nature of particular ideologies (Charteris-Black, 2004, p. 34). Charteris-Black argues that metaphor analysis should be a central component of Critical Discourse Analysis because metaphors are used pervasively to convey evaluations and therefore constitute part of the ideology of texts.

CMA demonstrates tremendous interdisciplinary feature which enables us to see associations across otherwise unrelated areas of human enquiry. CMA breaks the limitation of CMT in that 1) the research data comes from corpus instead of intuition or introspection; 2) cognitive approaches to metaphor are emphasized without neglecting the rhetorical function of metaphor; 3 ) it is a new complement to critical discourse analysis. Metaphor has the tendency to arouse the emotions. It can be seen as a speech act and exerts a direct influence on how people perceive the reality.

Building on the analytical steps of Cameron and Low (1999, p. 88), Charteris-Black establishes the three analytical stages of critical metaphor analysis including metaphor identification, metaphor interpretation and metaphor explanation (2004, pp. 35-41). The approach to metaphor identification has two stages: the first requires a close reading of a sample of texts with the aim of identifying candidate metaphors. Words that are commonly used with a metaphorical sense are then classified as metaphorical keywords and it is possible to measure the presence of such keywords quantitatively in the corpus. The second stage is a further qualitative phase in which corpus contexts are examined to determine whether each use of a keyword is metaphoric or literal. Metaphor identification involves establishing a relationship between metaphors and the cognitive and pragmatic factors that determine them. This involves the identification of conceptual metaphors, and where feasible, conceptual keys. Conceptual metaphors and conceptual keys are abstract inferences from the metaphors provided by linguistic instantiations. The inference of conceptual metaphors from the surface linguistic metaphors can help us identify the patterns of relationship among metaphors that account for their meaning. Similarly, interrelating conceptual metaphors through the identification of conceptual keys can help to account for coherence in particular discourse. For instance, LIFE IS A STRUGGLE FOR SURVIVAL, ECONOMIC LIFE IS A STRUGGLE FOR PROFIT and SPIRITUAL LIFE IS A STRUGGLE FOR SALVATION are the conceptual keys that account for many of the metaphors in the discourse of sports reporting, politics and religion. A hierarchical cognitive model of metaphor is shown as Figure 1. 

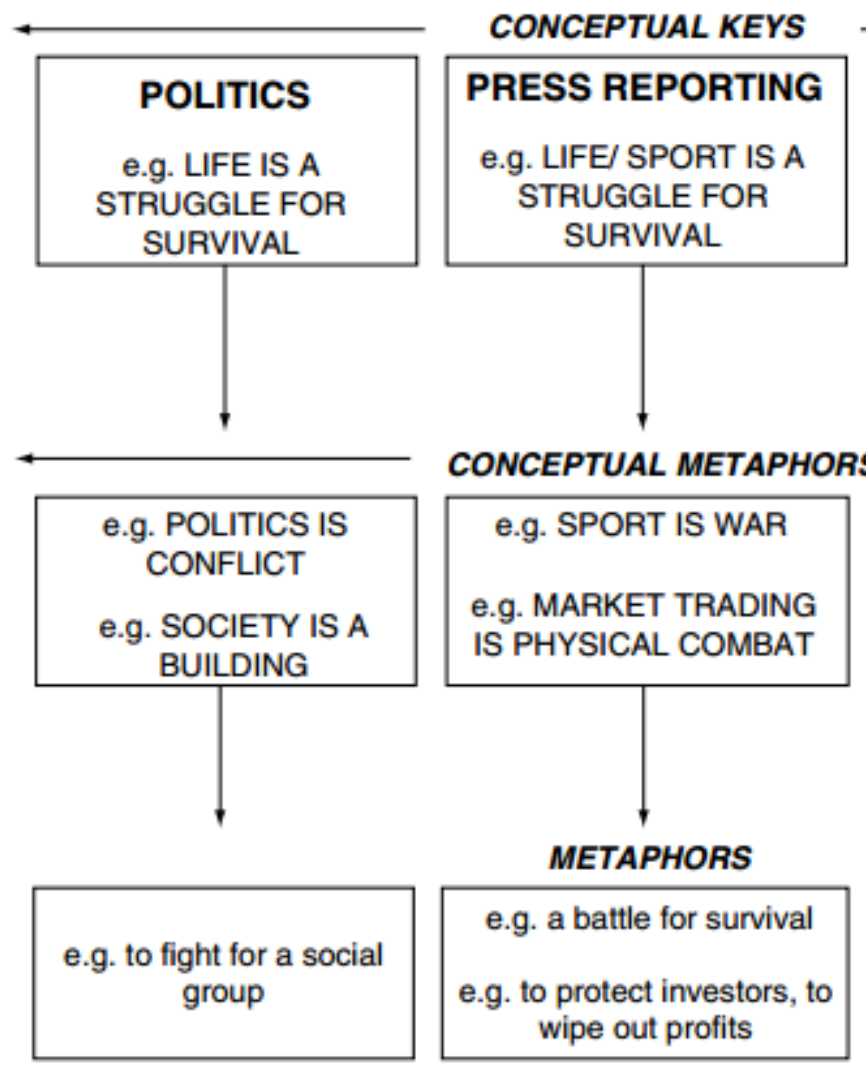

\section{CONCEPTUAL METAPHORS}
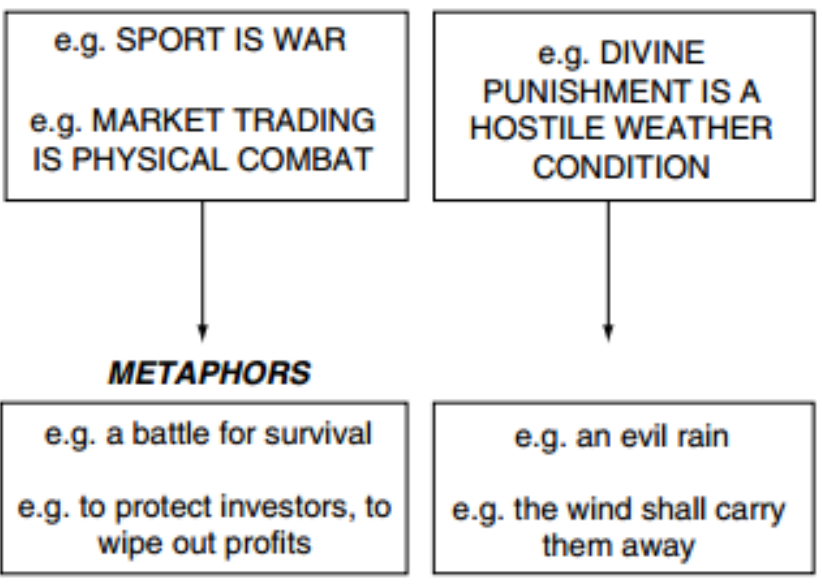

Figure 1. A hierarchical cognitive model of metaphor (Charteris-Black, 2004, p. 245)

Explanation of metaphors involves identifying the social agency that is involved in their production and their social role in persuasion. It unearths the formation process of conceptual metaphors and conceptual keys and enables us to know about the persuasive function of metaphors. In a sense, it is identifying the discourse function of metaphors that permits us to establish their ideological and rhetorical motivation. According to CMA, there is no deterministic motivation of metaphor use and the communicative purpose within a particular context will activate the affective potential of metaphor by exploiting individual and social resource. Individual resources can be sub-divided into three components including cognitive and affective (experiential meaning), pragmatic (contextual meaning) and linguistic (linguistic meaning) considerations. The social bases for metaphor choice are ideology (political belief), culture (group identity) and history (collective memory). Traditional approaches to metaphor exclusively focus on linguistic considerations and cognitive linguistic approaches exclusively concentrate on the individual experiential basis of metaphor. CMA insists that the core function of metaphor is persuasion which can be explained with reference to both social and individual considerations. The discourse model of CMA for metaphor is demonstrated as Figure 2. 
INDIVIDUAL RESOURCES

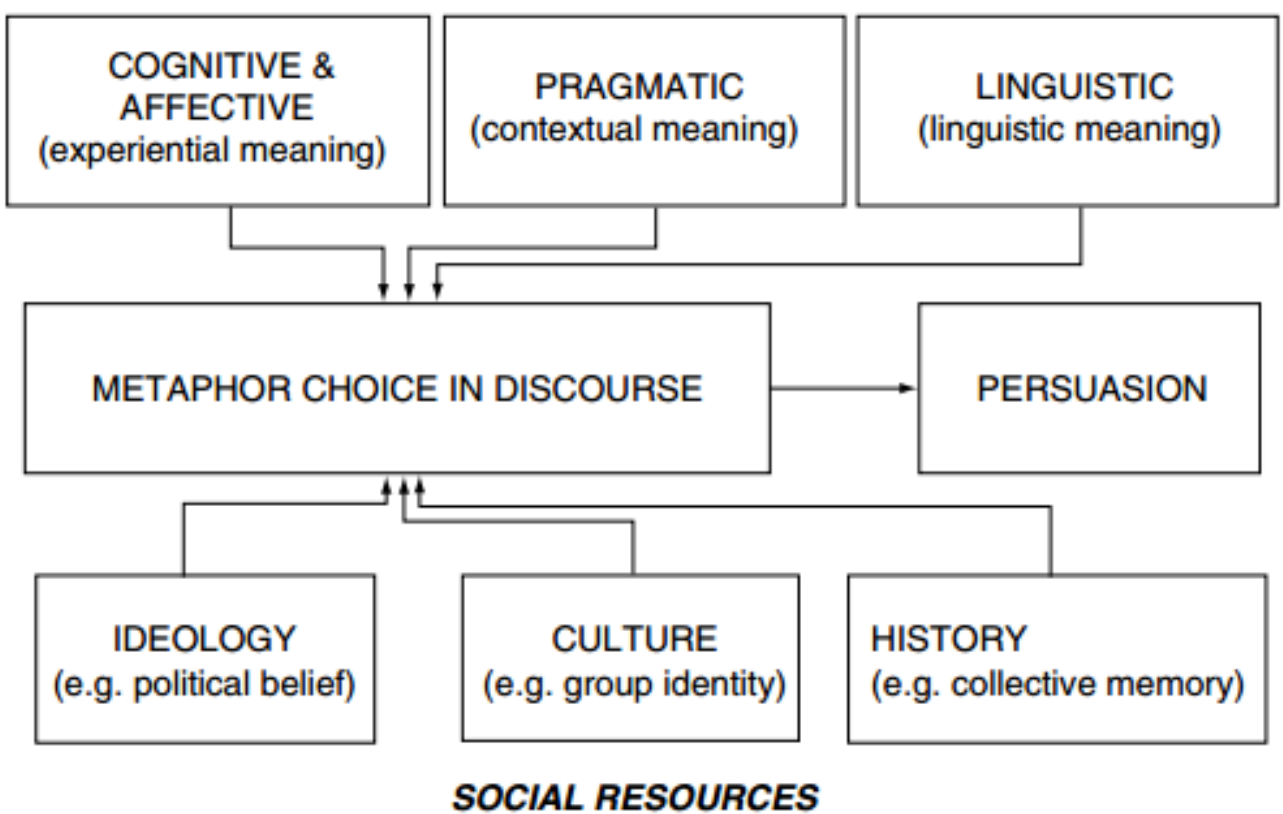

Figure 2. A discourse model for metaphor (ibid, p. 248)

\section{Method}

\subsection{Corpus Data}

The corpus used in the study is the news articles under Economy column of China Daily, the only national English-language newspaper in China. Committed to helping the world know more about China and the country's integration with the international community, China Daily is regarded as one of the country's most authoritative English media outlets and an important source of information on Chinese politics, economy, society and culture. It also serves as important reading materials for high-end Chinese readers who want to know more about the world. English-speaking staff reporters, correspondents and editors with the newspaper group are known for their professionalism, ethnics, enthusiasm and creativity. The 1.2-million-word corpus of Business Media Discourse consists of 2566 articles collected from the Business Economy column of ChinaDaily.com, the most influential newspaper issued in the mainland China, which has gathered the year 2014's most newsworthy China stories.

\subsection{Metaphor Identification Procedure}

MIP is the result of six years of work by ten experienced metaphor researchers called Pragglejaz Group (2007). It is a tool for linguistic metaphor identification in natural discourse and looks like a straightforward and easy method for metaphor identification.

There are four steps of metaphor identification procedure: 1) identify the contextual meaning of the lexical unit; 2) check if there is a more basic meaning of the lexical unit. If there is, establish its identity; 3 ) determine whether the more basic meaning of the lexical unit is sufficiently distinct from the contextual meaning; 4) examine whether the contextual meaning of the lexical unit can be related to the more basic meaning by some form of similarity (Steen et al., 2010, p. 25).

\subsection{Analyzing Procedures}

There are three steps in this study. The first one is to prepare for the checklist of the lemmas in the domain of WAR. Scholars have put forward different standards of classification. Crawford Camiciottoli (2007) compiled lists of items representing five root metaphors commonly found in the discourse of business and economics: ORGANIC, MECHANICAL, WARFARE, LIQUIDS and SPORTS. Koller (2004) makes lists of items in the domains of WAR, SPORTS, GAMES and an alternative ROMANCE under the topic of Marketing and Sales, FIGHTING, MATING, FEEDING and alternative DANCING and ROMANCE under the topic of Mergers and 
Acquisition. This study will synthesize all lexical items in the domain of WAR in this study, there are 62 lexical items of WAR metaphor, which is shown as Table 1.

Table 1. Lexical items of WAR metaphor

arm, assault, attack, backfire, barrier, battle, beleaguer, beset, blitz, blood, bomb, bruise, brutal, bulwark, campaign, casualty, combat, conquer, cut-throat, defeat, destructive, devastated, defend, dominate, enemy, eradicate, fight, fierce, front, guard, halt, havoc, hit, hostile, invade, kill, launch, manoeuvre, mobilize, ravage, raid, retaliate, safeguard, shoot, soldier, struggle, surrender, survive, targeting, take over, threat, trench, triumph, troops, truce, veteran, victory, war, weapon, wins, withdraw. alliance

The second step is to use Word Smith Tools 5.0 (specifically the concordance feature of the program) to capture all of the instances of the above lemmas as well as the lexemes they include (for example, the lemma campaign can be split up into campaigns, campaigned, campaigning, campaigner) in order to avoid missing some metaphorical expressions. Not all the lemmas listed above have their items realized as metaphorically used. Either these lemmas show no existence in the corpus or they exist but only have literal meaning, namely non-metaphorical expressions. The concordance output was then subjected to a qualitative analysis in order to isolate metaphorical expressions from non-metaphorical expressions.

The third step is to identify the metaphorical expressions. In general, our research follows the practice of metaphor identification procedure suggested by Steen et al. (2010). The verbal expressions are labeled as V, the nominal as $\mathrm{N}$, and the adjective and adverbs are marked as J. L stands for literal meaning, i.e., non-metaphorical expressions. The importance of reading concordance lines is highlighted in the following examples. In (1), battle has the literal meaning while in (2), it is a metaphorical expression.

(1) It was the central site of the temporary government set up by the Communist Party of China and the main battle area between the CPC and the Kuomintang in the 1930s (CHD Economy, 2014/07/04).

(2) Nevertheless, overall foreign demand for US Treasury securities is expected to remain strong in 2014, helped by the US Congress and the administration reaching an agreement in February that will put off any battle over raising the debt ceiling until March 2015 (CHD Economy, 2014/07/12).

\section{Results and Analysis}

The results will be presented and analyzed according to the three stages of CMA.

\subsection{Linguistic Level: Metaphor Identification}

Among all the 62 lexical items listed in Table 1, only 40 of them have their items realized as metaphorical expressions, as shown in Table 2. The total metaphorical expressions amount to 2490, among which 1436, or $57.67 \%$ are nouns, 1037 , or $41.65 \%$ are verbs and only 17 , or $0.68 \%$ are adjectives, which lags far behind the nominal and adjective ones. This quantitative analysis also reveals that metaphorical expressions of WAR show a nominal bias in our corpus. The three most frequently used items are target (1169), launch (369) and hit (284), which stands for the outbreak, process and results of a war in a real sense.

Table 2. The results of WAR metaphor

\begin{tabular}{llc}
\hline Lemma & Lexeme & Total \\
\hline TARGET & target, to target & 1169 \\
LAUNCH & launch, to launch & 369 \\
HIT & hit, to hit & 284 \\
FORCE & force, to force, forceful & 223 \\
BARRIER & barrier & 86 \\
WIN & winner/win, to win & 35 \\
STRUGGLE & struggle, to struggle & 31 \\
FRONT & front, to front & 24 \\
FIGHT & fight/-er, to fight & 23 \\
\hline
\end{tabular}




\begin{tabular}{|c|c|c|}
\hline TAKE OVER & takeover, to take over & 23 \\
\hline SAFEGUARD & safeguard, to safeguard & 20 \\
\hline THREAT & threat & 19 \\
\hline BATTLE & battle/-ground/-field, to battle, embattled, & 17 \\
\hline FIERCE & battle & 15 \\
\hline ARM & fierce & 15 \\
\hline CAMPAIGN & arm/amour/army. to arm & 14 \\
\hline WITHDRAW & campaign/campaigner, to campaign & 14 \\
\hline HALT & withdrawal, to withdraw & 11 \\
\hline MOBILIZE & halt, to halt & 10 \\
\hline SURVIVE & mobilization, to mobilize & 10 \\
\hline WAR & to survive, survivor, survival & 10 \\
\hline DEFEND & war/warfare/warrior, warlike, warring & 9 \\
\hline COMBAT & defendant, defensive, to defend & 9 \\
\hline GUARD & combat/to combat/combative & 7 \\
\hline DOMINATE & guard, to guard & 6 \\
\hline VICTORY & domination, to dominate & 6 \\
\hline WEAPON & victory, victorious & 5 \\
\hline SHOOT & weapon, weaponry & 4 \\
\hline TRENCH & shootout/shot/-gun, to shoot & 3 \\
\hline RETALIATE & to en/retrench, trench & 3 \\
\hline ERADICATE & retaliation, to retaliate & 3 \\
\hline BESET & eradicate, to eradicate & 3 \\
\hline HAVOC & beset, to beset & 2 \\
\hline VETERAN & havoc & 2 \\
\hline ASSAULT & veteran & 1 \\
\hline ATTACK & assault, to assault & 1 \\
\hline BACKFIRE & attack/-er, to attack & 1 \\
\hline DESTRUCTIVE & backfire, to backfire & 1 \\
\hline CONQUER & destructive & 1 \\
\hline \multirow[t]{2}{*}{ INVADE } & conquer, to conquer & 1 \\
\hline & invasion, to invade & \\
\hline
\end{tabular}

\subsection{Cognitive Level: Metaphor Interpretation}

"War and peace" is a recurring theme in the historical development of human beings. Although most of us today don't undergo real war, we can gain some basic experience on war via different media resources. Our knowledge of war tells us the main participants in a war are belligerent armed forces from two or more states or countries. They fight for territory or resources at the cost of many manpower and financial resources. The war takes place on the battleground. The generals command the war and decide on various strategies. The soldiers are allocated tasks and will be entitled with different ranks according to their contributions in a battle. The war will undergo different stages, leading to a decisive victory of one side. Similarly, the economic events have the specific target of earning profits. The main participants in the economic events are effective workforce from different departments and the CEO is the strategist. The managers in different departments lead the workforce to struggle for the profits. The duties and positions of the workforce are assigned according to their strength and professions. They compete with others in the profitable markets. Strategies are vital in the decisive victory of the competition with other companies and industries. They expand the market to promote the competitive advantage on the one 
hand and protect the existing market from being occupied on the other hand. The projection of these elements of a war in a real sense onto the economic events is shown as Table 3.

Table 3. The metaphorical mapping of ECONOMY IS WAR

\begin{tabular}{ll}
\hline WAR domain & ECONOMY domain \\
\hline targets in war & aims of economic event \\
weapons in war & means to gain advantage \\
troops in war & workforce in economic events \\
battleground of war & profitable market and industry \\
outbreak of war & the start of economic event \\
manoeuvres of war & economic policy and strategy \\
military invasion in war & entrance into new market \\
barrier of war & drag on economic expansion \\
defence in war & economic protection \\
results of war & results of economic event \\
\hline
\end{tabular}

Part of the ontological correspondences and linguistic instantiations underlying the metaphorical mapping can be demonstrated as follows. Description of these conceptual levels improves our understanding of their role in ideology because it provides a point of access to the cognitive mechanism under the linguistic instantiations.

\subsubsection{Elements in Economic Activity Are Elements in War}

Many slots in the schema of WAR, such as weapons, arms, target, threats are found mapped onto the slots in the schema in ECONOMY.

\subsubsection{Aims of Economic Activity Are Targets in War}

The noun target is predominant with 1169 instances. According to OED, target is "a light round shield or buckler; a small targe". In the domain of war, target means resource we want to seize or the territory we are eager to occupy. In the domain of economy, economic growth, market share, exportation, investments are all the targets that the firm or the country wants to hit. All the policy is implemented on the basis of these targets. In (3), domestic annual GDP is a target based on which the job market indicator can adjust the macro-policies.

(3) He stressed the importance of this data, saying the nation's top leadership requires a more specific job market indicator before setting the annual GDP growth target and adjusting macroeconomic policies (CHD Economy, 2014/12/31)

\subsubsection{Means to Gain Advantage in Economic Activity Are Weapons in War}

There is no doubt that arms and weapons are essentials in all military operations. These are very important criterion to measure the military strength. Advanced weapons can uplift the possibility of victory in any form of battles. Superior troops and armies can prevent a firm or a country from any crisis. Weapons, arms, troops in real war are projected onto the domain of economy. Something that can forge the competitive edge such as economic policy, superior strategies, first-hand information can be economic weapons, arms.

(4) Speaking of the EU's trade defense measures, the Italian official said for Europe the anti-dumping measures should be the last "weapon" to use (CHD Economy, 2014/12/19).

(5) The ministry said in a statement that the case is another victory of China in challenging the US abuse of trade remedy measures with legal weapons (CHD Economy, 2014/07/08).

(6) One high-profile initiative after the plenum's announcement came in February when Sinopec, as China Petroleum and Chemical Corp is known, said it would open at least 30 percent of its massive retail and marketing arm to private investors (CHD Economy, 2014/04/10).

(7) The IPMS will remove risks and ensure property investors are armed with reliable and transparent information, said Martin Bruehl, head of international investment management at Union Investment Real Estate, a major German open-ended fund provider (CHD Economy, 2014/12/26). 


\subsubsection{Forces Put in Economic Activity Are Generals and Troops in War}

Good commanders are like the generals in a real war. They can intelligently direct the war by putting forward advanced strategies. In (9) and (10), the middle-income group and female entrepreneurs are playing important roles in the economic war. Veterans who experience numerous battles are sophisticated and expert leaders in the economic war in (11). Despite the socialist market economy in China, government intervention is very pivotal in Chinese economy. They can mobilize financial and physical resources to prepare for a battle in (12) and (13).

(8) Bloomberg's China Real Activity Index for such new drivers expanded 11.9 percent in October from a year earlier, while a gauge of the "old" forces including real estate investment, ferrous-metal ore production and output of State-owned enterprises expanded 5.3 percent, the slowest since May 2009 (CHD Economy, 2014/12/10).

(9) The middle-income group will be the main force to stabilize domestic demand, he said (CHD Economy, 2014/12/22).

(10) Zhu Rui, the president of the CAWE, said that female entrepreneurs are necessary forces to drive the world's economic and social development. Compared to male business leaders, females are more cautious, precise and sensible with company management, she added (CHD Economy, 2014/12/05).

(11) That makes the valuation very high, and that may not be a very interesting stock from our point of view, said the investment bank veteran, who for 21 years worked at Goldman Sachs, where he managed the Investment Review Committee process for the company's US research department (CHD Economy, 2014/01/28).

(12) The central government has promised a "more forceful" fiscal policy next year to hedge against the economic slowdown. As of Sept 30, the government held 4.1 trillion yuan of cash in the central bank. Even if half of that money was mobilized, that would be the equivalent of 13.4 percent of total fiscal expenditure this year (CHD Economy, 2014/12/30).

(13) An unidentified government employee in east Zhoushan city complained that "everyone" in the government has been mobilized to lure investment projects (CHD Economy, 2014/02/19).

(14) "With the integration of Beijing, Tianjin and Hebei province, more and more resources will be mobilized to give more chances to a Tianjin FTZ", said Bai (CHD Economy, 2014/12/29).

\subsubsection{Profitable Markets and Industry Are Battleground in War}

Battleground is the place where the battle takes place and the contenders move aggressively towards each other. In the sense of economy, many countries or firms fight for entering new markets, or expanding their territories.

(15) The EIU says India will become a "key battleground for luxury brands as the retail market opens up to foreign investment" (CHD Economy, 2014/05/12).

(16) Cab-calling services have become an unexpected battlefield between Tencent and Alibaba, which have been locked in a fierce race to attract customers by offering generous rebates to both drivers and passengers to use their cab-booking smart phone apps and payment systems (CHD Economy, 2014/03/07).

\subsubsection{The Process of Economic Activity is the Process of War}

The process of WAR constructs the movement scenario where the contenders move aggressively in their fight over territory. There are most lexical items that represent the process of war, such as barrier, attack, assault, defend, invade, struggle and the like.

\subsubsection{The Start of Economic Activity Is the Outbreak of War}

Based on our knowledge, war usually wastes a large amount of manpower and money. In other words, before the war breaks out, funds should necessarily be raised and the manpower needs to be mobilized. In the domain of economy, the wars are launched to achieve the goals of winning more customers and investors, earning more profits, or expanding the market.

(17) The Isle of Man, a self-governing dependent territory of the British Crown, is launching a promotional campaign in China to attract more Chinese investors for its economic expansion (CHD Economy, 2014/12/19).

(18) The four-day meeting, which opened on Monday in Beijing, came as top policymakers seek a balance between maintaining growth and launching reforms, amid concerns that the Chinese economy will substantially slow down in the coming years (CHD Economy, 2014/10/21). 
(19) Britain's former industrial hub Manchester is trying to forge ever closer ties with China, and on Wednesday a delegation of Manchester business representatives launched an investment portfolio of the city-region's opportunities in Beijing (CHD Economy, 2014/10/22).

5.2.2.2 Economic Steps or Actions Taken for Market in Economic Activities Are Military Maneuvres Taken in War

Items like battle, fight, attack and invade vividly describe the process of a war. These items emphasize the confrontational, competitive, aggressive and potentially destructive effects of the target domain, more generally the antagonistic nature of it and dramatize various forms of competition among the enterprises concerned in the discourse of economy. These experiences of war can be metaphorically transferred to the domain of ECONOMY in describing the steps or actions with the aim to gain an advantage over competitors.

(20) Slightly higher power consumption in the first half of 2014 indicated China is still battling to arrest a slowing economy, analysts said (CHD Economy, 2014/07/16).

(21) It has become common consensus that curbing trade protectionism is crucial in fighting the current global economic downturn (CHD Economy, 2014/12/19).

(22) But the real economy, primarily the manufacturing industry, has been under "unprecedented" attack in recent years because of factors including soaring costs and an appreciating currency, said Gao (CHD Economy, 2014/04/08)

(23) "If the government really wants to let the market play a 'decisive' role in allocating resources, it must leave the territory it invaded, replacing its 'positive' list' with a 'negative list'," Liu added. (CHD Economy, 2014/03/18).

\subsubsection{Drag on the Expansion of Economy Is the Barrier in War}

Barriers are something that can stop one side from the access to success. The global competition among different countries is increasingly fierce. Many countries are trying to protect domestic economy from the threats of other countries. Trade barriers are government-induced restrictions on international trade. In our corpus, trade, which has 86 instantiations, mostly collocates with trade in (24) or investment in (25). Most trade barriers work on the same principle: the imposition of some sort of cost on trade that raises the price of the traded products. International trade aims to increase the efficiency of production under the theory of comparative advantage. While the trade barrier just destroys such efficiency, thus impeding the smooth development of each country.

(24) China has signed 12 free trade agreements, lowering trade barriers in 20 countries and districts for Chinese business. China has also wrapped up free trade agreement negotiations with South Korea and Australia (CHD Economy, 2014/12/15).

(25) China and South Korea have effectively reached a free trade agreement that would remove or sharply reduce trade and investment barriers between two nations (CHD Economy, 2014/11/18).

\subsubsection{The Actions that Protect the Economy Is the Defence in War}

Every country and industry in the global market are exposed to external assaults and challenges, they can take some strategies to protect themselves.

(26) The biggest producers from the Organization of the Petroleum Exporting Countries are reducing prices to defend their market share (CHD Economy, 2014/10/25).

(27) We expect the central bank to maintain a relatively supportive credit environment to defend the nation's GDP growth target (CHD Economy, 2014/10/21).

\subsubsection{The Result of Economic Activity Is the Result of War}

A war usually ends with triumphs, peaceful negotiations havoc or ceasefires, and there are winners, losers, victims or survivors, which also applies to economic activities.

(28) But China's Ministry of Commerce hailed the ruling as a "significant victory" because it rejected the US' concurrent use of multiple punitive measures against Chinese imports (CHD Economy, 2014/03/28).

(29) In a study of 44 nations, Oxford Economics Ltd listed Russia, Saudi Arabia, Norway, Italy and the Netherlands among the biggest losers from cheaper crude. Winners include the Philippines, China, India and Indonesia (CHD Economy, 2014/12/18).

(30) China has implemented multiple measures to help the country's numerous small firms survive economic hardship and has seen positive results, a senior Chinese official has said (CHD Economy, 2014/09/06). 
(31) However, the future for investment in China is still very promising, and international companies are not considering a withdrawal, Ge said (CHD Economy, 2014/09/09).

In the fierce global market, the survival of the fittest in the theory of evolution also works. The firms which have weak strength will face the risks of being replaced or taken over by the powerful ones in the form of mergers and acquisitions. And sometimes the results may turn to be out of expectations, like a backfire in the sense of war.

(32) Fosun's takeover battle for Club Mediterranee and its latest offer that values the French holiday operator at $\$ 1.15$ billion give an indication of things to come next year, bankers said (CHD Economy, 2014/12/24).

(33) "Financial liberalization could end up backfiring. If you allow interest rates to go up and the market a free rein in determining the cost of capital while you have a legacy of debt within local governments and SOEs (State-owned enterprises), you are going to get the problems of non-performing loans and asset prices going the wrong way. You can't afford to get the sequencing wrong" (CHD Economy, 2014/01/06).

\subsection{Social-Cultural Analysis: Metaphor Interpretation}

CMA suggests that both individual and social resources cooperate to achieve the persuasive function of metaphor in specific discourse. The articles in China Daily are for the most part be composed by Chinese journalists. So the typical Chinese ideology, group identity and collective memory are the main components for the social resource which influence the choice of WAR metaphor.

The first definition of war in OED, a descriptive dictionary of the English language which traces the historical development of the English language, is "hostile contention by means of armed forces, carried on between nations, states, or rulers, or between parties in the same nation or state; the employment of armed forces against a foreign power, or against an opposing party in the state". The second definition of war is that it rhetorically refers to "any kind of active hostility or contention between living beings, or of conflict between opposing forces or principles". These two definitions indicate that there are various forms and belligerent parties of a war in a real sense in history. And war has extends its basic meaning of violent incidents to metaphorical meaning of conflict and disagreement in daily life. This metaphorical usage is conventionalized. The dictionary also notes that one can "declare", "wage" or "levy" war, and can "make war". Therefore, the concept of war has entrenched in human mind and becomes part of human ideology. It is acknowledged that in the long history course of Chinese nation, human beings involve themselves in agricultural and handicraft production in order to live and breed. Various fights among people such as class struggle and ethnic war are also continuous in history. The legend says that the earliest war can be traced back to the times of Chinese Yan Emperor and Huang Emperor. It is after the battle of Banquan and Zhuolu that Huang Emperor unify central China. Looking back on the history, the replacement of dynasties, the expelling of the invasion and the disputes of the dignitaries are all solved with the form of warfare. Sheng bai nai bing jia chang shi (胜败乃兵家常事) is inherited from generation to generation. Troops and warfare is essential part of social life. The five-thousand-year history of civilization of China is also a five-thousand-year history of warfare. In other words, war is a recurrent historical phenomenon that exerts tremendous effects on the development of human history. Although the scenario of battlefield in the ancient times has been submerged in the long course of Chinese history, the ancient troops and warfare are closely associated with contemporary lives. For example, the frequently used Chinese idioms like da dao kuo fu (大刀阔斧) si mian chu ge (四面楚歌), yi gu zuo qi (一鼓作气), yan qi xi gu (偃旗息鼓) are highly frequent in our language use. The expressions related to warfare like price war, trade war, struggle against corruption, battle against pollution frequently occurred in our daily life. German military theorist Clausewitz argues that warfare is the augmentative fight which makes enemies submit to our willpower. All war behaviors are political behavior. Some Chinese scholars claim that expressions about warfare are rich and diversified because the entrenched thinking on war is easy to map onto other conceptual domains. Although sports events, love affairs, political conflict and business competition do not resort to violent means, they share the same aim with war. They all tend to force other persons to bend to our will. Warfare is a means to solve the conflict of interest. Eubank (2000, p. 13)-citing Karl von Clausewitz (1832)-War belongs to the province of business competition, which is also the conflict of human interest.

As for the individual resource, the division of ourselves and enemies makes the language in the news articles vivid and boosts the readers' interest. These linguistic instantiations successfully dramatize the opposition between different industries or countries and emphasizes the severity of competition of global economy. Meanwhile, it boosts morale within a group and encourages the members to compete against a common enemy, such as foreign competitors faced by each country. These aggressive scenarios dramatize the challenges and threats from companies at home and abroad. On the one hand, these companies try to keep and expand their domestic market share, as the powerful nations to expand their territory. On the other hand, they compete with 
experienced internationals and remove the barriers to enter new markets, as generals and soldiers defend their home territory against powerful foreign invaders. All imply that domestic companies and industries are engaging in a war for survival. From this respect, metaphor serves as a rhetorical device for the language in these news articles. The readers of these news articles are high-educated people who keep a watchful eye on the economic development at home and abroad. The frequent adoption of WAR metaphor can construct the cognitive model of competition in the mind of these readers, thus arousing their emotions and more attention to the economic development from the pragmatic perspective. Koller (2004) asserts that the enforced usage of the metaphor will root even more firmly in business discourse and will also have an impact on how business is being done. Zhang (2011) holds that such an animate metaphor as WAR can transform the discussed entities and events in the abstract domain of ECONOMY into something concrete that could act or be acted upon because wars are human-oriented. This makes it possible to highlight both the initiative of entities and the constraints imposed on them, which are the core of free market ideology and socialist ideas respectively.

\section{Conclusion}

Metaphor can create new worlds of experience through the complex interaction of meaning, language and life. In our study, metaphor shows frequent occurrences in the discourse of economy in that China Daily is an expert journalists-to-non-expert readers' interaction media. The frequent use of WAR metaphor can help the readers better understand the abstract economic entities through direct physical knowledge of war. Meanwhile, China Daily is a good resource for language learners. The abundant metaphorical expressions can help the students better enhance the metaphor awareness and master the technical terms of economy. However, in allowing us to focus on one aspect of a concept, a metaphorical concept can keep us from focusing on other aspects of the concept that are in consistent with that metaphor (Lakoff \& Johnson, 1980, p. 10). Therefore, when we use conceptual elements in the domain of WAR to understand the abstract entities and phenomenon in the domain of ECONOMY, the competitiveness of economic activities will be highlighted while the cooperative principles will be hid. However, the current global market advocates a win-win situation even though the resource is scarce. One of the ten principles of economics says "Trade makes everyone better off".

\section{Acknowledgments}

This study was supported by the project "Economic Metaphors in Chinese and English Business Media Discourses" (16TS12) and the Key Research Project of Philosophy and Social Science of Ministry of Education of China (15JZD048).

\section{References}

Cameron, L., \& Low, G. (1999). Researching and Applying Metaphor. Cambridge: Cambridge University Press. https://doi.org/10.1017/CBO9781139524704

Charteris-Black, J. (2004). Corpus approaches to critical metaphor analysis. Basingstoke, England: Palgrave Macmillan. https://doi.org/10.1057/9780230000612

Chen, M. (2010). Metaphor and Ideology in Economic Discourse. Chengdu: Si Chuan University Press.

Crawford, C. B. (2007). The language of business studies lectures. John Benjamins B.V. https://doi.org/10.1075/pbns.157

Eubanks, P. (2000). A War of Words in the Discourse of Trade: The Rhetorical Constitution of Metaphor. Carbondale, Ill.: Southern Illinois University Press.

$\mathrm{Hu}, \mathrm{C}$. (2014). A Corpus-based analysis of bubble metaphor in economics. Journal of PLA University of Foreign Language, 1, 18-31.

Hu, C., \& Chen, Z. (2015). Inflation metaphor in contemporary American English. Higher Education Studies, 5(6), 21-35. https://doi.org/10.5539/hes.v5n6p21

Koller, V. (2004). Metaphor and Gender in Business Media Discourse: A Critical Cognitive Study. Basingstoke, Hants: Palgrave Macmillan. https://doi.org/10.1057/9780230511286

Kövecses, Z. (2010). Metaphor: A Practical Introduction (2nd ed.). Oxford: Oxford University Press.

Kress, G. (1989). Linguistic Processes in Sociocultural Practice (2nd ed.). Oxford University Press.

Lakoff, G. (1987). Women, fire, and dangerous things: What categories reveal about the mind. Chicago: The University of Chicago Press. https://doi.org/10.7208/chicago/9780226471013.001.0001

Lakoff, G. (1993). The contemporary theory of metaphor. In A. Ortony (Ed.), Metaphor and Thought (2nd ed., pp. 202-251). Cambridge: Cambridge University Press. https://doi.org/10.1017/CBO9781139173865.013 
Lakoff, G., \& Johnson, M. (1980). Metaphors we live by. Chicago: University of Chicago Press.

Lakoff, G., \& Turner, M. (1989). More than Cool Reason: A Field Guide to Poetic Metaphor. University of Chicago Press. https://doi.org/10.7208/chicago/9780226470986.001.0001

Mankiw, N. G. (2010). Macroeconomics (7th ed.). Worth Publishers.

Quinn, N. (1991). The cultural basis of metaphor. In J. W. Fernandez (Ed.), Beyond Metaphor: The Theory of Tropes in Anthropology (pp. 56-93). Stanford: Stanford University Press.

Steen, G. J., Aletta, G., Dorst, J., Berenike, H. A. A., Kaal, T. K., \& Trijntje, P. (2010). A Method for Linguistic Metaphor Identification: From MIP to MIPVU. Amsterdam: Benjamins. https://doi.org/10.1075/celcr.14

Wu, E. (2010). The Metaphorical Thoughts in the Cognitive Domain of Economics. Hangzhou; Zhe Jiang University Press.

Zhang, L. (2011). A Critical Metaphor Analysis of Representation in English and Chinese Discourse. Tianjin: NanKai University Press.

\section{Copyrights}

Copyright for this article is retained by the author(s), with first publication rights granted to the journal.

This is an open-access article distributed under the terms and conditions of the Creative Commons Attribution license (http://creativecommons.org/licenses/by/4.0/). 